Nina M. Anđelić

Associate Professor University of Belgrade Faculty of Mechanical Engineering

Vesna O. Milošević-Mitić
Professor
University of Belgrade
Faculty of Mechanical Engineering
Ana S. Petrović
Assistant
University of Belgrade

\section{Stress Constraints Applied to the Optimization of a Thin-Walled Z-Beam}

One approach to the optimization of a thin-walled open section Z-beam subjected to the bending and to the constrained torsion is considered. For given loads, material and geometrical characteristics, the problem is reduced to the determination of minimum mass i.e. minimum crosssectional area of structural thin-walled beam of the chosen shape. The area of the cross-section is assumed to be the objective function. The stress constraints are introduced. The Lagrange multiplier method is applied. Solutions of analitically obtained expressions for the mathematical model, numerical solutions, as well as the saved mass, are calculated for three loading cases.

Keywords: thin-walled beams, optimal dimensions, stress constraints, saved mass.

\section{INTRODUCTION}

Thin-walled beams find a wide application in construction and machinery industry. They are widely applied in many structures manufactured using thinwalled elements (shells, plates, thin-walled beams) which are subjected to complex loads. In most structures it is possible to find the elements in which, depending on loading cases and the way they are introduced, the effect of constrained torsion is present and its consequences are particularly evident in the case of thin-walled profiles. Thin-walled structures consist of a wide and growing field of engineering applications which seek efficiency in strength and cost by minimizing material. The result is a structure in which the stability of the components i.e. the "thin walls" is often the primary aspect of the behaviour and the design.

In the past, there were a large number of research studies on the behavior of thin-walled structures. The earliest development of the theory of thin-walled structures is associated with the beginning of the $20^{\text {th }} \mathrm{c}$. The most prominent contributors to the development of this theory were Timoshenko and Gere [1]. Vlasov [2] contributed largely to the theory of thin-walled structures by developing the theory of thin-walled open section beams. Kollbruner and Hajdin [3] expanded the field of thin-walled structures by a range of works.

In recent years emerged many works devoted to the optimization of thin-walled cross-sections. Solving various optimization problems has been discussed in a number of works and monographs. First of all Gajewski and Życzkowski [4] provided a review of optimal designing of thin-walled structures, including shells and rods. Afterwards, Magnucki and Monczak [5] presented variational and parametrical optimization of open crosssection of a thin-walled beam subjected to bending.

Received: May 2013, Accepted: July 2013

Correspondence to: Dr Nina Anđelić

Faculty of Mechanical Engineering,

Kraljice Marije 16, 11120 Belgrade 35, Serbia

E-mail: nandjelic@mas.bg.ac.rs

doi:10.5937/fmet1403237A

(C) Faculty of Mechanical Engineering, Belgrade. All rights reserved
Tian and $\mathrm{Lu}$ [6] optimized cold-formed open-channel sections with and without the lips subjected to compressive load.

Many studies have been conducted on optimization problems, treating the cases where geometric configurations of structures are specified and only the dimensions of structural members and the areas of their cross-sections are determined in order to attain the minimum structural weight or cost (Lewiński [7], Mijailović [8], 2010, Rong and Yi, [9]).

Then, a series of works appear where the optimization problem of various cross-sections, such as triangular cross-section [10], I-section [11], [12]) or $U$ section [13] are solved by using the Lagrange multiplier method.

The idea of this paper is to expand these works and to develop an approach to the optimization of a thinwalled $Z$ cross-section beams.

\section{SUBJECT OF RESEARCH}

The starting points during the formulation of the basic mathematical model are the assumptions of the thinwalled-beam theory, on one side, and the basic assumptions of the optimum design, on the other.

The $\mathrm{Z}$ cross-section as very often used thin-walled profile in steel structures is considered in the present paper as the object of optimization. The determination of its optimal dimensions is a very important process but not always the simplest one. The aim of the paper is to determine the minimum mass of the whole beam, i.e. the minimum area $A$ of the cross-section of the considered beam for the given loads and material properties (1)

$$
A=A_{\text {min }}
$$

The formulation of the problem is restricted to the stress analysis of thin-walled beams with open sections.

The cross-section of the considered beam (Fig. 1) with principal centroidal axes $X_{\mathrm{i}}(\mathrm{i}=1,2)$ has the center and not the axis of symmetry. It is assumed that its flanges have equal widths $b_{1}=b_{3}$, and thicknesses $t_{1}=t_{3}$, and that its web has the width $b_{2}$ and thickness $t_{2}$. 

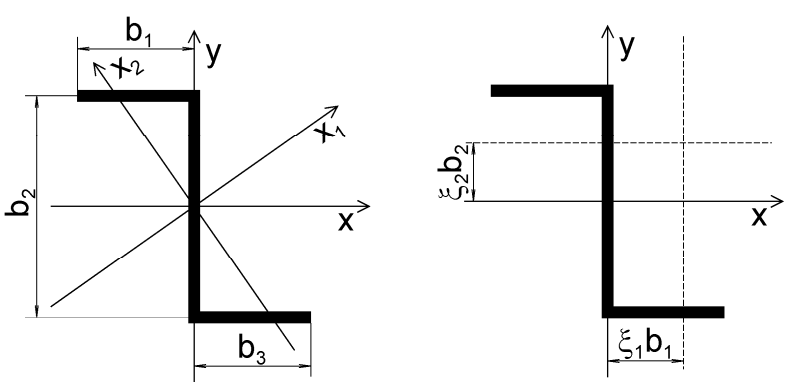

Figure 1. Cross-section

It is also assumed that the loads are applied in two longitudinal planes, parallel to the centroidal axes $x$ and $y$ (Fig. 1) at the distances $\xi_{\mathrm{i}} b_{\mathrm{i}}(\mathrm{i}=1,2)$. If applied in such a way, the loads will cause the bending moments acting in the above mentioned two planes parallel to the longitudinal axis of the beam, and as their consequence the effects of the constrained torsion will appear in the form of the bimoment causing the stresses that depend on the boundary conditions [3].

Formulation of the structural design optimization problem plays an important role in the numerical solution process. A particular choice of the objective function and constraints affect the final solution, and efficiency and robustness of the solution process.

In mathematics and computer science, an optimization problem is the problem of finding the best solution from all feasible solutions. The process of selecting the best solution from various possible solutions must be based on a prescribed criterion known as the objective function. The idea of an objective function, can be considered in general terms as a mathematical representation of how the variables that effect suitable alternatives can be evaluated and compared.

In the considered problem the cross-sectional area (2) will be treated as an objective function and it is obvious from the Fig. 1 that

$$
A=\sum_{1}^{3} b_{i} t_{i}
$$

or, because $b_{1}=b_{3}$,

$$
A=A\left(b_{1}, b_{2}\right)=2 b_{1} t_{1}+b_{2} t_{2},
$$

where $t_{\mathrm{i}}$ and $b_{\mathrm{i}}$ are thicknesses and widths of the flanges and the web [3].

The constraints treated in the paper are the stress constraints. The expressions (3) for equivalent bending moments [14] taking into account the influence of the bending moments around centroidal axes $x$ and $y$, denoted as $M_{x}$ and $M_{y}$ respectively, will be used

$$
\overline{M_{x}}=\frac{M_{x}-M_{y}\left(\frac{I_{x y}}{I_{y}}\right)}{1-\frac{I_{x y}^{2}}{I_{x} \cdot I_{y}}}, \overline{M_{y}}=\frac{M_{y}-M_{x}\left(\frac{I_{x y}}{I_{x}}\right)}{1-\frac{I_{x y}^{2}}{I_{x} \cdot I_{y}}},
$$

where $I_{x}, I_{y}$ are the moments of inertia of the crosssectional area about the centroidal axes $x$ and $y$, and $I_{x y}$ is the product of inertia.
The normal stresses are caused by the bending moments $\overline{M_{x}}$ and $\overline{M_{y}}$ and by the bimoment $B$ in the case of constrained torsion, and they will be denoted as $\overline{\sigma_{x}}$ and $\overline{\sigma_{y}}$ and $\sigma_{\omega}$ respectively [3].

In the case when the bending moments are acting in the planes parallel to the longitudinal axis (Fig. 1) at the distances $\xi_{i} b_{i}(i=1,2)$ the bimoment (4) as their consequence will appear and it can be expressed as the function of the bending moments and the eccentrities of their planes $\xi_{\mathrm{i}} b_{\mathrm{i}}(\mathrm{i}=1,2)$ in the following way $[3,14]$

$$
B=\xi_{1} b_{1} \overline{M_{x}}+\xi_{2} b_{2} \overline{M_{y}} .
$$

For the allowable stress $\sigma_{0}$ the constraint function can be written as

$$
\varphi=\varphi(\sigma)={\overline{\sigma_{x} \text { max }}}+{\overline{\sigma_{y}}}_{\text {max }}+\sigma_{\omega_{\max }} \leq \sigma_{0} .
$$

The maximal normal stresses, are defined in the form $[3,14]$

$$
{\overline{\sigma_{x} \max }}=\frac{\overline{M_{x}}}{W_{x}},{\overline{\sigma_{y}}}_{\text {max }}=\frac{\overline{M_{y}}}{W_{y}}, \sigma_{\omega \max }=\frac{B}{W_{\omega}},
$$

where $W_{x}$ and $W_{y}$ are the section moduli for the longitidunal axes, and $W_{\omega}$ is the sectorial section modulus for the considered cross-section.

After the introduction of (6) into (5), the constraint function becomes

$$
\varphi=\frac{\overline{M_{x}}}{W_{x}}+\frac{\overline{M_{y}}}{W_{y}}+\frac{B}{W_{\omega}} \leq \sigma_{0} .
$$

The constraint function (7) is reduced to:

$$
\begin{aligned}
\varphi=\varphi\left(b_{1}, b_{2}\right) & =30 M_{x} \frac{1}{t_{1} b_{1} b_{2}\left(3+2 \frac{t_{2}}{t_{1}} \frac{b_{2}}{b_{1}}\right)}+ \\
& +3 M_{y} \cdot z \cdot \frac{9+\frac{t_{2}}{t_{1}} \frac{b_{2}}{b_{1}}}{t_{1} b_{1} b_{2}\left(3+2 \frac{t_{2}}{t_{1}} \frac{b_{2}}{b_{1}}\right)}+. \\
& +6 B \frac{1+\frac{t_{2}}{t_{1}} \frac{b_{2}}{b_{1}}}{t_{1} b_{1}^{2} b_{2}\left(1+2 \frac{t_{2}}{t_{1}} \frac{b_{2}}{b_{1}}\right)}-\sigma_{0} \leq 0
\end{aligned}
$$

The expression (8) represents the constraint function corresponding to the given stress constraints.

\section{SOLVING THE OPTIMIZATION PROBLEM}

\subsection{Analytic solution}

One of the most common problems is that of finding maxima or minima (in general, "extrema") of a function. The Lagrange multiplier method $[8,11,12,13,15]$ is a method for finding the extremum of the function of several variables when the solution must satisfy a set of 
constraints, and for the analogous problem in the calculus of variations. Lagrange multiplier, labeled as $\lambda$, measures the change of the objective function with respect to the constraint.

Applying the Lagrange multiplier method to the vector which depends on two parameters $b_{\mathrm{i}}(\mathrm{i}=1,2)$ the system of equations

$$
\frac{\partial}{\partial b_{i}}(A+\lambda \varphi)=0, \quad \mathrm{i}=1,2,
$$

will be obtained.

After the introduction of the expression (4) for the bimoment into the equation (8), the equation (9) can be reduced to the equation of the sixth order (10) whose solutions give the optimal values of the ratio (11)

$$
\sum_{k=1}^{6} c_{k} z^{k}=0
$$

where :

$-z=b_{2} / b_{1}$ is the optimal ratio of the lengths of the web and of the flange of the considered cross-section, and the coefficients $c_{k}$ in (10) are defined by:

$$
\begin{gathered}
c_{0}=60+144\left(\xi_{1}+\xi_{2}\right), \\
c_{1}=2 \psi\left(145+276 \xi_{1}+264 \xi_{2}\right)+36\left(3 \xi_{1}+4 \xi_{2}\right) \frac{M_{y}}{M_{x}}, \\
c_{2}=2 \psi\left\{4 \psi\left(55+38 \xi_{1}+27 \xi_{2}\right)-3\left[4-23\left(3 \xi_{1}+4 \xi_{2}\right)\right] \frac{M_{y}}{M_{x}}\right\}, \\
c_{3}=\psi^{2}\left\{4 \psi\left(50-75 \xi_{1}-84 \xi_{2}\right)-\left[123-76\left(3 \xi_{1}+4 \xi_{2}\right)\right] \frac{M_{y}}{M_{x}}\right\}, \\
c_{4}=-\psi^{3}\left\{8 \psi\left(31 \xi_{1}+24 \xi_{2}\right)+\left[208+75\left(3 \xi_{1}+4 \xi_{2}\right)\right] \frac{M_{y}}{M_{x}}\right\}, \\
c_{5}=-2 \psi^{4}\left[16 \psi \xi_{1}+31\left(2+3 \xi_{1}+4 \xi_{2}\right) \frac{M_{y}}{M_{x}}\right], \\
c_{6}=-8 \psi^{5}\left(2+3 \xi_{1}+4 \xi_{2}\right) \frac{M_{y}}{M_{x}} .
\end{gathered}
$$

It is obvious that the coefficients $c_{k}$ depend on the ratio of the bending moments and on the eccentrities $\xi_{1}$ and $\xi_{2}$ of their planes.

The results that follow were obtained by the analytical approach.

\subsection{Particular cases}

From the general case, when bending moments about both axes appear simultaneously with the bimoment, some particular cases can be considered, depending on the ratio $M_{y} / M_{x}$. The optimal ratios $z=b_{2} / b_{1}$ defined by (11) and obtained from the equation (10) are calculated for the ratios $M_{y} / M_{x}=0,0.1,0.5,1$; and for $\psi$ $=0.5,0.75,1$ and for $0 \leq \xi_{1} \leq 1 ; 0 \leq \xi_{2} \leq 1$.

The optimal values of $z$ for $M_{y} / M_{x}=0$ and $\psi=0$, 0.75 and 1.0, are shown in Tables 1, 2 and 3, and they are presented as the functions of $\xi_{1}$ and $\xi_{2}$.
Table 1. Optimal $z$ for $M_{y} / M_{x}=0, \Psi=0.5$

\begin{tabular}{|c|c|c|c|c|c|c|}
\hline$\xi_{1} \rightarrow$ & 0 & 0.2 & 0.4 & 0.6 & 0.8 & 1 \\
\hline$\xi_{2} \downarrow$ & & & & & & \\
\hline 0 & 12.11 & 7.87 & 5.42 & 4.50 & 4.02 & 3.73 \\
\hline 0.2 & 11.80 & 5.94 & 4.70 & 4.12 & 3.79 & 3.57 \\
\hline 0.4 & 6.88 & 4.95 & 4.24 & 3.85 & 3.61 & 3.44 \\
\hline 0.6 & 5.32 & 4.38 & 3.93 & 3.66 & 3.48 & 3.35 \\
\hline 0.8 & 4.57 & 4.02 & 3.71 & 3.51 & 3.37 & 3.27 \\
\hline 1 & 4.13 & 3.78 & 3.55 & 3.40 & 3.29 & 3.20 \\
\hline
\end{tabular}

Table 2. Optimal $z$ for $M_{y} / M_{x}=0, \Psi=0.75$

\begin{tabular}{|l|l|l|l|l|l|l|}
\hline$\xi_{1} \rightarrow$ & 0 & 0.2 & 0.4 & 0.6 & 0.8 & 1 \\
\hline$\xi_{2} \downarrow$ & & & & & & \\
\hline 0 & 8.05 & 5.25 & 3.61 & 3.00 & 2.68 & 2.49 \\
\hline 0.2 & 7.87 & 3.96 & 3.13 & 2.75 & 2.52 & 2.38 \\
\hline 0.4 & 4.58 & 3.30 & 2.83 & 2.57 & 2.41 & 2.30 \\
\hline 0.6 & 3.55 & 2.92 & 2.62 & 2.44 & 2.32 & 2.23 \\
\hline 0.8 & 3.05 & 2.68 & 2.48 & 2.34 & 2.25 & 2.18 \\
\hline 1 & 2.75 & 2.52 & 2.37 & 2.27 & 2.19 & 2.13 \\
\hline
\end{tabular}

Table 3. Optimal $z$ for $M_{y} / M_{x}=0, \psi=1$

\begin{tabular}{|l|l|l|l|l|l|l|}
\hline$\xi_{1} \rightarrow$ & 0 & 0.2 & 0.4 & 0.6 & 0.8 & 1 \\
\hline$\xi_{2} \downarrow$ & & & & & & \\
\hline 0 & 6.22 & 3.94 & 2.71 & 2.25 & 2.01 & 1.86 \\
\hline 0.2 & 5.90 & 2.97 & 2.35 & 2.06 & 1.89 & 1.78 \\
\hline 0.4 & 3.44 & 2.48 & 2.12 & 1.93 & 1.81 & 1.72 \\
\hline 0.6 & 2.66 & 2.19 & 1.97 & 1.83 & 1.74 & 1.67 \\
\hline 0.8 & 2.28 & 2.01 & 1.86 & 1.76 & 1.69 & 1.63 \\
\hline 1 & 2.07 & 1.89 & 1.78 & 1.70 & 1.64 & 1.60 \\
\hline
\end{tabular}

The highest and the lowest optimal values $z=b_{2} / b_{1}$ for $M_{y} / M_{x}=0.1,0.5,1$ are given in a shortened form in Table 4.

Table 4. Optimal $z$ for $M_{y} / M_{x}=0.1,0.5,1$ and $\psi=0.5,0.75,1$

\begin{tabular}{|c|c|c|}
\hline$M_{v} / M_{x}$ & $\psi$ & $z$ \\
\hline \multirow{3}{*}{0.1} & 0.5 & $2.92 \leq z \leq 5.54$ \\
\cline { 2 - 3 } & 0.75 & $1.99 \leq z \leq 4.38$ \\
\cline { 2 - 3 } & 1 & $1.52 \leq z \leq 3.70$ \\
\hline \multirow{3}{*}{0.5} & 0.5 & $2.56 \leq z \leq 2.74$ \\
\cline { 2 - 3 } & 0.75 & $1.78 \leq z \leq 2.19$ \\
\cline { 2 - 3 } & 1 & $1.36 \leq z \leq 1.86$ \\
\hline \multirow{3}{*}{1} & 0.5 & $2 \leq z \leq 2.41$ \\
\cline { 2 - 3 } & 0.75 & $1.60 \leq z \leq 1.66$ \\
\cline { 2 - 3 } & 1 & $1.28 \leq z \leq 1.37$ \\
\hline
\end{tabular}

From Tables $1-4$ it is obvious that the quantity $z$ is decreasing with the increase of eccentricities $\xi_{1}$ and $\xi_{2}$, ratio $\psi=t_{2} / t_{1}$ and the load ratio.

\subsection{The loading cases}

The obtained results are used for the calculation that follows. Some particular cases can be considered, depending on the loading case. In the present section, the cantilever Z-beam is fixed at one end and subjected to the concentrated bending moments. The loading cases when the concentrated bending moments are applied at the free end for three positions of the load plane with respect to the shearing plane are considered: 

a) $\xi_{1}=0, \xi_{2}=0$
b) $\xi_{1}=0.5, \xi_{2}=0$,
c) $\xi_{1}=1, \xi_{2}=0$.

The optimal values $z_{\text {opt }}$ are calculated as previously explained for each loading case:

- $\quad$ Loading case 1: $M_{y} / M_{x}=0\left(M_{x}=100 \mathrm{Nm}, M_{y}=0\right)$,

- Loading case 2: $M_{y} / M_{x}=0.1\left(M_{x}=100 \mathrm{Nm}, M_{y}=\right.$ $10 \mathrm{Nm}$ ),

- Loading case 3: $M_{y} / M_{x}=1\left(M_{x}=100 \mathrm{Nm}, M_{y}=\right.$ $100 \mathrm{Nm})$.

\section{NUMERICAL EXAMPLE AND ANALYSIS OF RESULTS}

As the numerical example, the considered cantilever beam of the length $l=1500 \mathrm{~mm}$, fixed at one end is subjected to the bending moments.

The numerical example is first done for the $\mathrm{Z}$ section with its initial dimensions of the flanges and of the webs corresponding to the standard profile $\mathrm{Z} 10$ (DIN 1027) $b_{1}=b_{3}=51.75 \mathrm{~mm}, b_{2}=92 \mathrm{~mm}$, having thick flange $t_{1}=8 \mathrm{~mm}$ and $t_{2}=6.5 \mathrm{~mm}$, with the ratio $\psi$ $=t_{2} / t_{1}=0.8125$ (Table 5). For the same initial dimensions of the lengths of flanges and webs, and the same ratio $\psi$, an example is also done for the case of thin flange $t_{1}=5 \mathrm{~mm}, t_{2}=4.1 \mathrm{~mm}$ (Table 6).

The model defined in such a way is considered as the "Initial model" having the "Initial area" of the crosssection. Starting from the initial relation $z_{\text {initial }}$ and for the initial wall thicknesses $t_{1}$ and $t_{2}$, the optimal relation $z_{\text {optimal }}$ is calculated defining the "Optimal area" of the cross-section. The results are given in Tables 5 and 6 . Then the "Initial stresses" are calculated for the considered loading cases 1, 2 and 3 and for the defined geometry of the cross-section.

\subsection{Minimum mass determination - results and discussion}

The problem is considered in two ways:

1) Optimal model no. 1. The optimal dimensions of the cross-sections $b_{1 \text { optimal }}$ and $b_{2 o p t i m a l}$ are obtained by equalizing the "Initial" and the "Optimal area" ( $\left.A_{\text {initial }}=A_{\text {optimal }}\right)$ and by using the calculated optimal relation $z$. In that case, the normal stress, lower than the initial one, is obtained $\left(\sigma_{\text {optimal }}<\sigma_{\text {initial }}\right)$. It represents optimal model no. 1 (Tables 5 and 6).

2) Optimal model no. 2. From the condition requiring that the stresses must be lower than the allowable one, i.e. the "Initial stress", the optimal values $b_{\text {1optimal }}$ and $b_{\text {2optimal }}$ are obtained using the calculated optimal relation $z$ and comparing the stress defined by the optimal geometrical characteristics of the "Initial stress". It represents optimal model no. 2. Starting from the optimal cross-sectional dimensions ( $b_{\text {loptimal }}$ and $b_{\text {2optimal }}$ ), the optimal - minimum cross-sectional area $A_{\text {min }}$ is calculated for each loading case and the results including the saved mass of the material are given in Tables 5 and 6 (presented at the end of the text).

From the Tables 5 and 6 it can be seen that for all loading cases the level of stresses is decreased in the Optimal model no. 1 with the area of the cross-section having the same value as in the "Initial model", and the saved mass of material is increased with respect to the initial stress limits in the Optimal model no.2, where the area is smaller than the initial one. The calculation showed that the maximum saved material is obtained in the Loading case 1 and the minimum in the Loading case 3 . This allows the conclusion that if the distance of the loading plane from the shearing plane is increased the optimization of the cross-section is less necessary to be done.

It is also interesting to notice the differences in the obtained results for the cases of thick (Table 5) and thin (Table 6) cross-section walls. It may be concluded that in the case of the thin walled cross-section normal stresses are a little bit higher but the saved mass is even much higher.

The results obtained by computation are verified by an example using finite element analysis (COSMOS program). The bracket is modeled by tetrahedron volumetric finite elements and the results were obtained for the stresses at nodes of elements in the clamped end. For the data shown in Table 5, loading case $3 \mathrm{~b}$, it is shown that the results obtained by computation and finite element coincide (Fig.2).

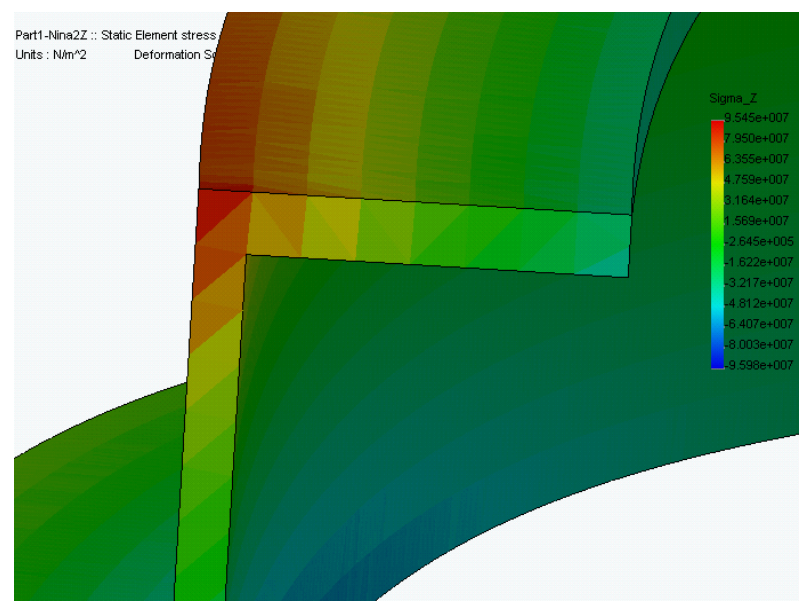

a

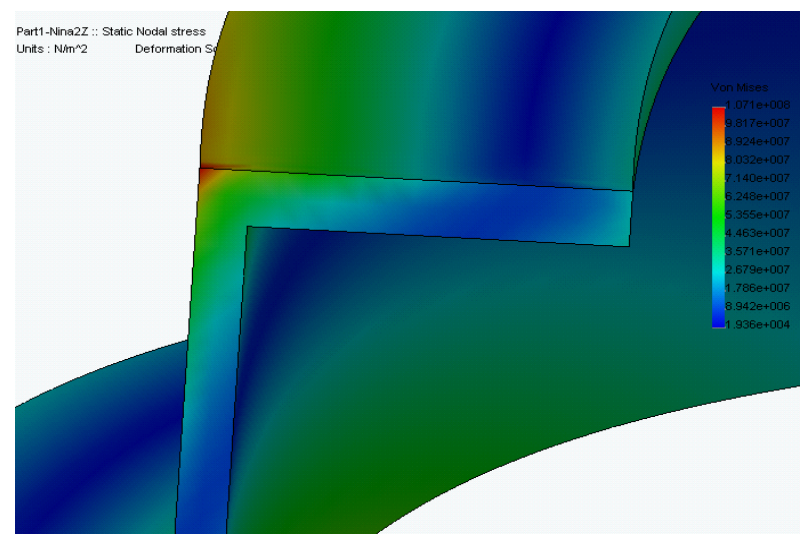

b

Figure 2. Normal stresses obtained by the Cosmos Program

\section{CONCLUSION}

The paper presents one approach to the optimization of the thin-walled $\mathrm{Z}$ - section beams, loaded in a complex way, using the Lagrange multiplier method. 
Accepting the cross-sectional area as the objective function and the stress constraints as the constrained functions, it is possible to calculate the optimal ratios of the webs and of the flanges of the considered thinwalled profiles in a very simple way.

In addition to the general case, some particular loading cases are considered. As the result of the calculation the modified constrained functions are derived as the polynomials of the sixth order. Attention is particularly directed to the calculation of the saved mass using the proposed analytical approach. It is also possible to calculate the saved mass of the used material for different loading cases.

The aim of the paper was the optimization of thinwalled elements subjected to the complex loads, and it may be concluded that the paper gives the general results permitting the derivation of the expressions that are recommendable for technical applications.

\section{ACKNOWLEDGMENT}

This work was supported by the Ministry of Science and Technological Development of Serbia funded projects TR 35011 and TR 35040.

\section{REFERENCES}

[1] Timoshenko, S.P. and Gere, J.M.: Theory of elastic stability, 2nd edn, Mc Graw-Hill, New York, 1961.

[2] Vlasov, V.Z.: Thin-Walled Elastic Beams, 2nd edn., Moscow, pp. 568 (English translation, Israel Program for Scientific Translation, Jerusalem, 1961).

[3] Kollbruner, C.F. and Hajdin, N.: Dunnwandige Stabe, Band 1, Springer Verlag, Berlin, 1970.

[4] Gajewski, A. and Życzkowski M.: Optimal structural design under stability constraints, Kluwer Academic Publishers, Dordrecht, 1988.

[5] Magnucki, K. and Monczak, T.: Optimum shape of open cross section of thin-walled beam, Eng. Optim, Vol. 32, pp. 335-351, 2000.

[6] Tian,Y.S. and Lu, T.J.: Minimum weight of coldformed steel sections under compression, Thinwalled structures, Vol. 42, No. 4, pp. 515-532, 2004.

[7] Lewiński, J.: Optimization of anti-symmetrical open cross-sections of cold-formed thin-walled beams, Journal of Theoretical and Applied Mechanics, Vol. 47, No. 3, pp. 553-571, 2009.

[8] Mijailović, R.: Optimum design of lattice-columns for buckling, Structural and Multidisciplinary Optimization, Vo. 42, No. 6, pp. 897-906, 2010.
[9] Rong, J.H. and Yi, J.H.: A structural topological optimization method for multi-displacement constraints and any initial topology configuration, Acta Mechanica Sinica, Vol. 26, No.5, pp. 735-744, 2010.

[10] Selmic, R., Cvetkovic, P., Mijailovic, R. and Kastratovic G., 2006, Optimum Dimenzions of Triangular Cross-Section in Lattice Structures, Meccanica, Vol. 41, No. 4, pp. 391-406, 2006.

[11] Andjelić, N. and Miloševic-Mitić V.: Optimum design of thin-walled I-beam subjected to stress constraint, Journal of Theoretical and Applied Mechanics, Vol. 50, No. 4, pp. 553-571, 2012.

[12] Andjelić, N.: One view to the optimization of thinwalled open sections subjected to the constrained torsion, FME Transactions, Vol. 35, No. 1, pp. 2328, 2007.

[13] Andjelić, N.: Torsional analysis of open section thin-walled beams, FME Transactions, Vol. 40, No. 2, pp. 93-98, 2012.

[14]Bojanić, Z.: Theory of Elasticity, Part 2 (in Serbian), University of Belgrade, Faculty of Mechanical Engineering, Belgrade, 2002.

[15]Zoller, K.: For precise interpretation of the Lagrange equation of the second type (In German), Art. Ingenieur-Archiv, Vol. 41, No. 4, 270-277, 1972.

\section{НАПОНСКА ОГРАНИЧЕЊА ПРИМЕЊЕНА НА ОПТИМИЗАЦИЈУ ТАНКОЗИДИХ Z - ПРОФИЛА}

\section{Нина М. Анђелић, Весна О. Милошевић-Митић, Ана С. Петровић}

Разматран је један приступ оптимизацији танкозидих отворених попречних пресека облика Z - профила, изложених савијању и ограниченој торзији. За дата оптерећења, материјал и геометријске карактеристике, проблем се своди на одређивање минималне масе, односно минималне површине попречног пресека конструктивних танкозидих попречних пресека изабраног облика. Површина попречног пресека је изабрана за функцију циља. Уведена су напонска ограничења. Примењује се Метода Лагранжовог множитеља. Резултати аналитички добијених једначина за математички модел, нумеричка решења, као и уштеда у маси, израчунати су за три случаја оптерећења. Неки резултати су проверени применом програма COSMOS. 
Table 5. Normal stresses and saved mass: $t_{1}=8 \mathrm{~mm}$ and $t_{2}=6.5 \mathrm{~mm}, z_{\text {initial }}=1.78$

\begin{tabular}{|c|c|c|c|c|c|c|c|c|}
\hline \multicolumn{2}{|c|}{$\begin{array}{c}\text { Loading } \\
\text { Case }\end{array}$} & $z$ optimal & $\begin{array}{c}\sigma_{\text {in }} \\
{[\mathrm{MPa}]}\end{array}$ & $\begin{array}{l}\sigma_{\text {opt. no. } 1} \\
{[\mathrm{MPa}]}\end{array}$ & $\begin{array}{l}\sigma_{\text {opt. no.2 }} \\
{[\mathrm{MPa}]}\end{array}$ & $\begin{array}{c}\mathrm{A}_{\mathrm{in}}=\mathrm{A}_{\mathrm{opt} \text { no. } 1} \\
{\left[* 10^{-3} \mathrm{~m}^{2}\right]}\end{array}$ & $\begin{array}{c}A_{\min }=A_{o p t} \text { no. } 2 \\
{\left[* 10^{-3} \mathrm{~m}^{2}\right]}\end{array}$ & $\begin{array}{c}\text { Saved mass } \\
{[\%]}\end{array}$ \\
\hline \multirow{3}{*}{1} & $\mathrm{a}$ & 5.58 & 13.4 & 7.5 & 13.4 & \multirow{3}{*}{1.426} & 1.033 & 27.56 \\
\hline & $\mathrm{b}$ & 2.99 & 25.9 & 24.6 & 25.9 & & 1.398 & 1.96 \\
\hline & $\mathrm{c}$ & 2.29 & 38.3 & 37.8 & 38.3 & & 1.418 & 0.56 \\
\hline \multirow{3}{*}{2} & $\mathrm{a}$ & 4.18 & 15.9 & 12.7 & 15.9 & \multirow{3}{*}{1.426} & 1.278 & 10.38 \\
\hline & $\mathrm{b}$ & 2.45 & 30 & 29.1 & 30 & & 1.410 & 1.12 \\
\hline & $\mathrm{c}$ & 2.07 & 44.2 & 43.9 & 44.2 & & 1.422 & 0.28 \\
\hline \multirow{3}{*}{3} & $\mathrm{a}$ & 1.53 & 38.2 & 37.9 & 38.2 & \multirow{3}{*}{1.426} & 1.424 & 0.14 \\
\hline & $\mathrm{b}$ & 1.54 & 99.8 & 99.1 & 99.8 & & 1.422 & 0.28 \\
\hline & $\mathrm{c}$ & 1.55 & 161.4 & 160.3 & 161.4 & & 1.423 & 0.21 \\
\hline
\end{tabular}

Table 6. Normal stresses and saved mass: $t_{1}=5 \mathrm{~mm}$ and $t_{2}=4.1 \mathrm{~mm}, z_{\text {initial }}=1.78$

\begin{tabular}{|c|c|c|c|c|c|c|c|c|}
\hline \multicolumn{2}{|c|}{$\begin{array}{c}\text { Loading } \\
\text { Case }\end{array}$} & $z_{\text {optimal }}$ & $\begin{array}{c}\sigma_{\text {in }} \\
{[\mathrm{MPa}]}\end{array}$ & $\begin{array}{l}\sigma_{\text {opt. no.1 }} \\
{[\mathrm{MPa}]}\end{array}$ & $\begin{array}{c}\sigma_{\text {opt. no.2 }} \\
{[\mathrm{MPa}]}\end{array}$ & $\begin{array}{c}\mathrm{A}_{\mathrm{in}}=\mathrm{A}_{\mathrm{opt} \text { no. } 1} \\
{\left[* 10^{-3} \mathrm{~m}^{2}\right]}\end{array}$ & $\begin{array}{c}\mathrm{A}_{\min }=\mathrm{A}_{\mathrm{opt} \text { no. } 2} \\
{\left[* 10^{-3} \mathrm{~m}^{2}\right]}\end{array}$ & $\begin{array}{c}\text { Saved mass } \\
{[\%]}\end{array}$ \\
\hline \multirow{2}{*}{1} & $\mathrm{a}$ & 5.58 & 2.1 & 11.9 & 2.1 & \multirow{2}{*}{0.891} & 0.510 & 42.76 \\
\hline & $\mathrm{c}$ & 2.29 & 61.3 & 60.5 & 61.3 & & 0.745 & 16.39 \\
\hline 2 & $\mathrm{a}$ & 4.18 & 25.4 & 20.3 & 25.4 & 0.891 & 0.631 & 29.18 \\
\hline \multirow{3}{*}{3} & $\mathrm{a}$ & 1.53 & 61.1 & 60.6 & 61.1 & \multirow{3}{*}{0.891} & 0.703 & 21.09 \\
\hline & $b$ & 1.54 & 159.6 & 158.5 & 159.6 & & 0.743 & 16.61 \\
\hline & $\mathrm{c}$ & 1.55 & 258.2 & 256.5 & 258.2 & & 0.752 & 15.60 \\
\hline
\end{tabular}

